\title{
Changes in the characteristics of 'wet' and 'dry' Red Sea Trough over the Eastern Mediterranean in CMIP5 climate projections
}

\author{
Assaf Hochman ${ }^{1}$ (D) - Dorita Rostkier-Edelstein ${ }^{2,3}$ (1) $\cdot$ Pavel Kunin $^{4} \cdot$ Joaquim G. Pinto ${ }^{1}$ (D)
}

Received: 28 April 2020 / Accepted: 28 October 2020 / Published online: 11 November 2020

(C) The Author(s) 2020

\begin{abstract}
The Eastern Mediterranean resides on the border between the temperate and semi-arid and arid climate zones, and is thus influenced by both mid-latitude and sub-tropical weather systems. Precipitation and extreme weather in this region are mainly associated with either Cyprus Lows or the "wet" Red Sea Troughs. Current regional climate projections indicate that the region may become warmer and drier in future decades. Here, we analyze the influence of enhanced greenhouse gas forcing on the climatological properties of the 'wet' and 'dry' Red Sea Trough (WRST \& DRST, respectively). With this aim, a regional synoptic classification and a downscaling algorithm based on past analogs are applied to eighteen rain stations over the main ground water basins in Israel. The algorithms are applied to the NCEP/NCAR reanalysis data for 1986-2005 and to eight CMIP5 model simulations for the historical (1986-2005) and end of the century (2081-2100) climate conditions according to the RCP8.5 scenario. For the historical period, the CMIP5 models are largely able to represent the characteristics of the Red Sea Trough. Based on the multi-model mean, significant changes are found for WRST and DRST for the late XXI Century. First, an increase in the meridional pressure gradient is found for both the WRST and the DRST, implying stronger horizontal winds. Furthermore, a significant decrease in the occurrence of the WRST $(-20 \%)$ and a significant increase in the frequency of the DRST $(+19 \%)$ are identified. Accordingly, the persistence of the WRST decreases $(-9 \%)$, while for DRST increases $(+9 \%)$. The decline in the frequency of WRST occurs primarily in the transition seasons, while the increase for DRST is found throughout the wet season. In total, the daily rainfall associated with the WRST system is projected to significantly decline ($37 \%$ ) by the end of the XXI century. These results document the projected changes in a dominant synoptic system in this area, which can facilitate a better estimation of the arising challenges, e.g., related to shortage of water resources and associated political unrest, reduced agricultural potential, and increased air pollution and forest fires. Such a pathway can ultimately foster novel mitigation strategies for water resources management and regional climate change adaptation.
\end{abstract}

Keywords Active Red Sea Trough · Synoptic classification · Climate change · Eastern Mediterranean · Global warming · Middle East

Supplementary Information The online version contains supplementary material available at https://doi.org/10.1007/s00704-02003449-0.

Assaf Hochman

assaf.hochman@kit.edu

1 Department of Tropospheric Research, Institute of Meteorology and Climate Research, Karlsruhe Institute of Technology,

Karlsruhe, Germany

2 Freddy and Nadine Hermann, Institute of Earth Sciences, The Hebrew University of Jerusalem, Jerusalem, Israel

3 Department of Environmental Physics, Environmental Sciences Division, Israel Institute for Biological Research, Ness-Ziona, Israel

4 Life Science Research Israel, Ness-Ziona, Israel

\section{Introduction}

The Mediterranean region has been recognized as a "hot spot" of climate change, given its location on the border between temperate climate to the north and semi-arid to arid climate to the south (Giorgi 2006). Precipitation in this region strongly depends on the frequency of Mediterranean cyclones (e.g., Trigo et al. 1999; Lionello et al. 2016) and other rain producing synoptic systems, sometimes of tropical/sub-tropical origin (e.g., Krichak et al. 1997). Climate projections indicated that this region will become warmer and drier with increasing greenhouse gas forcing (e.g., Lionello et al. 2014; Samuels et al. 2017), which is often associated with strong changes in 
the occurrence of synoptic systems in the region (Ulbrich et al. 2009; Raible et al. 2010; Zappa et al. 2015a; Hochman et al. 2018a).

Compared to the Western Mediterranean, the Eastern part is less affected by systems arising from the North Atlantic basin, while it is influenced by an enhanced number of synoptic systems of tropical/sub-tropical origin (e.g., Alpert et al. 2005). Indeed, precipitation in the Eastern Mediterranean is mainly associated with either Cyprus Lows or Red Sea Troughs. Cyprus Lows are Mediterranean cyclones of local origin (e.g., Trigo et al. 2002; Lionello et al. 2016) and contribute to about $80 \%$ of precipitation over Israel (Saaroni et al. 2010). Just like other Mediterranean cyclones, Cyprus Lows have been projected to significantly decrease in their frequency, persistence, and daily precipitation yield by respectively $35 \%, 8 \%$, and $26 \%$, towards the end of the XXI century (Hochman et al. 2018a, 2020a). The Red Sea Trough is an extension of the Sudan Monsoon Low, which is part of the equatorial low-pressure system (e.g., Ashbel 1938; El Fandy 1948; Awad and Mashat 2019). When the northern part of the Red Sea is affected by easterly flow, a trough tends to develop northward at the lee of the mountains surrounding the Red Sea (e.g., Krichak et al. 1997). The Red Sea Trough is often associated with warm and dry conditions, resulting from easterly/ south-easterly flow from the desert at near surface levels, and such conditions are denominated 'Dry' Red Sea Trough (DRST; Fig. 1b; Tsvieli and Zangvil 2005). Forest fires (e.g., Kutiel and Kutiel 1991), air pollution (e.g., Koch and Dayan 1992), and easterly wind storms (e.g., Saaroni et al. 1998) are often associated with DRST conditions. On other situations, the horizontal trough axis may be tilted towards the Mediterranean Sea when accompanied by an upper level midlatitude trough extending over the Mediterranean. Such conditions favor the development of thunder storms and intense rain events and are named 'Wet' Red Sea Trough (WRST; Fig. 1a; e.g., Tsvieli and Zangvil 2005; Krichak et al. 2012; De Vries et al. 2013), often leading to flash floods (Kahana et al. 2002; Shentsis et al. 2012) and sand and dust storms (e.g., Gasch et al. 2017). While large attention has been given to Mediterranean cyclones and Cyprus Lows, less attention has been given to the Red Sea Trough, particularly within the context of climate change.

Still, several studies have focused on the identification and characterization of the Red Sea Trough (e.g., Alpert et al. 2004a; Tsvieli and Zangvil 2005; Krichak et al. 2012; Awad and Almazroui 2016). Here, we identify the Red Sea Trough based on the semi-objective synoptic classification (Alpert et al. 2004a) as modified by Hochman et al. (2018a). This classification is the most widely used and has been found to closely reflect the salient features of Eastern Mediterranean synoptic systems both in reanalysis and General Circulation Models (GCMs), including that of the Red Sea Trough (Hochman et al. 2018a, b, 2019,
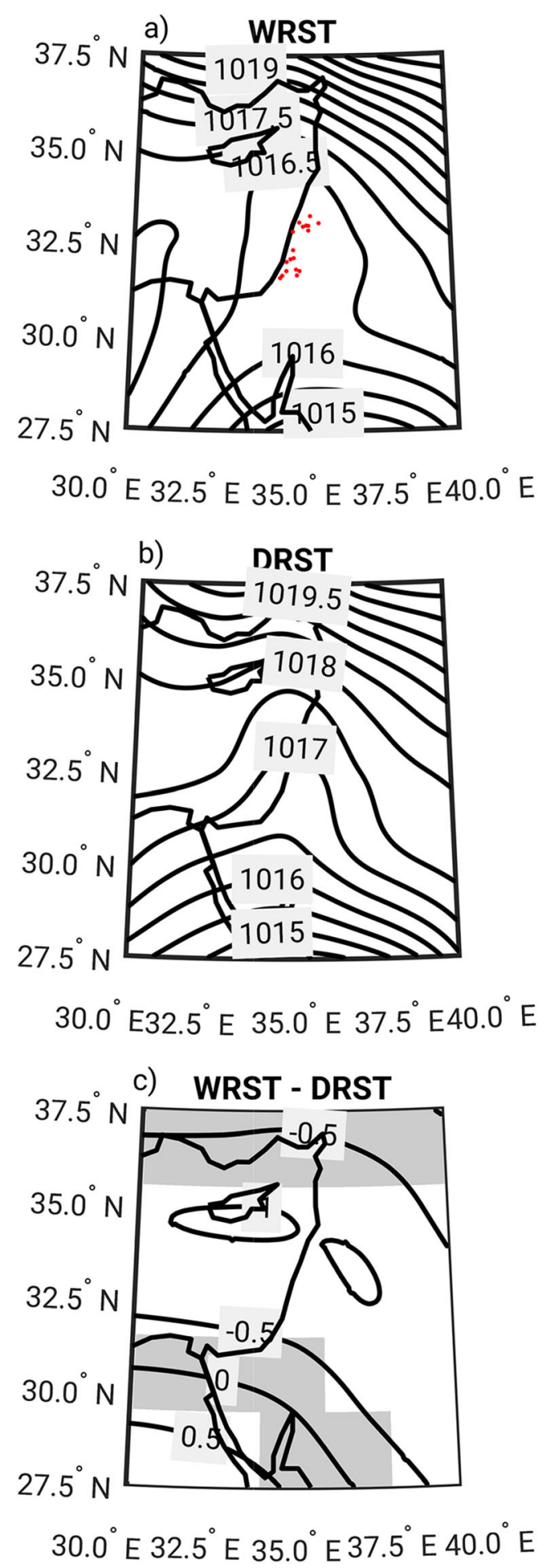

Fig. 1 The study region. a Mean sea level pressure (hPa) composite map of 'Wet' Red Sea Trough (WRST). The location of the eighteen rain stations used in this study (red points). b Mean sea level pressure (hPa) composite map of 'Dry' Red Sea Trough (DRST). $\mathbf{c}$ The difference between WRST and DRST (hPa). The composite maps are computed for 1986-2005. Differences are significant using the student's $t$ test at the 5\% significance level except for grid points shaded in gray

2020a). The WRST and DRST are categorized using station daily rain amounts for Israel. 
While GCMs are a comprehensive tool for climate studies, they have clear shortcomings in representing the synoptic activity in complex topographic regions like the Mediterranean (e.g., Ulbrich et al. 2009; Lionello et al. 2014). One main concern is the model's horizontal resolution still being of the order of $\sim 100 \mathrm{~km}$. This prevents GCMs from simulating adequately some effects like wind channeling in complex terrain and sea-land interactions (e.g., Maraun and Widmann 2018). To bridge the gap between GCMs and local climate variables, downscaling techniques have been established. These techniques consist of either dynamical downscaling with a higher resolution regional climate model, statistical approaches, or a combination of both (e.g., Wilby and Wigley 1997; Giorgi et al. 2009; Maraun et al. 2010; Maraun and Widmann 2018). In recent years, coordinated international frameworks such as COST-VALUE (Maraun et al. 2015; Huth 2019) and CORDEX (Giorgi et al. 2009) were formed and provided evidence of the added value of the different downscaling techniques for various applications.

Here, we use a statistical downscaling algorithm (RostkierEdelstein et al. 2016), based on past analogs, a concept first proposed by Lorenz (1969). This technique enables a good reproduction of the observed mean amounts, their inter-annual, and spatial variability of seasonal rainfall over the main ground water basins of Israel (Rostkier-Edelstein et al. 2016; Hochman et al. 2020b).

The Red Sea Trough resides over the Eastern Mediterranean on $\sim 20 \%$ of the days, with a pronounced peak during autumn and an additional, lesser peak, during winter (Alpert et al. 2004a, b). Alpert et al. (2004a) identified a considerable increase in the frequency of the Red Sea Trough from 1960-2000. The authors hypothesized a possible link between the enhanced occurrence of the DRST in recent decades and the decreasing trend in rainfall over the Eastern Mediterranean. However, Saaroni et al. (2019) did not identify any significant changes in the occurrence of the Red Sea Trough for 1979-2016, using an automatic identification algorithm. Regarding future climate projections, Peleg et al. (2015) identified an increase in the occurrence of the WRST focusing on models from the fifth phase of the Coupled Model Intercomparison Project (CMIP5) and using a classification algorithm based on one specific grid point near the coast of Israel. Thus, there is no general consensus on how global warming may influence the Red Sea Trough. This question is especially relevant in terms of water resource availability in light of the observed and projected reductions in precipitation levels attributed to the Cyprus Low system (e.g., Alpert et al. 2004a; Hochman et al. 2018a).

The purpose of this study is to estimate how the projected increase in greenhouse gas forcing may influence the climatological properties of the WRST and DRST. With this aim, we specifically focus on changes in Sea Level Pressure (SLP) patterns, frequency, persistence, annual cycle, and the associated rainfall yield over the region.

\section{Data}

Daily data on a $2.5^{\circ} \times 2.5^{\circ}$ horizontal grid spacing are obtained from the National Center for Environmental Prediction/National Center for Atmospheric Research reanalysis 1 project (NCEP/NCAR; Kalnay et al. 1996) for the period 1986-2005. GCM data are retrieved from the World Data Center for Climate - Deutsches Klimarechenzentrum GmbH (WDCC-DKRZ, https:// cera-www.dkrz.de) data portal, for eight CMIP5 models (Table 1; Taylor et al. 2012) following the choice of Hochman et al. (2018a). The grid spacing varies from $0.94^{\circ} \times 1.25^{\circ}$ to $1.9^{\circ} \times 3.75^{\circ}$, depending on the model (Table 1). These models are able to adequately capture the relevant qualitative features of the dynamics, frequency, and annual cycle of the synoptic systems over the Eastern Mediterranean, including those of the Red Sea Trough (Hochman et al. 2018a, b, 2019). The analysis is based on CMIP5 historical (1986-2005) simulations and on the NCEP/NCAR reanalysis archive. The considered future period corresponds to the end of the XXI century (2081-2100) following the representative concentration pathway of $8.5 \mathrm{~W} \mathrm{~m}^{-2}$ (RCP8.5) scenario (Van-Vuuren et al. 2011). Both the synoptic classification and the analogs statistical downscaling algorithms (Sect. 3) require smoothed synoptic scale atmospheric fields. Therefore, we have chosen to use the NCEP/ NCAR reanalysis as a reference for the CMIP5 models as they have similar spatial and temporal resolution. Saaroni et al. (2019) have recently provided evidence that using higher resolution data to identify the Red Sea Trough actually reduces the ability to discriminate between the Red Sea Trough and other synoptic systems. Therefore, the preference of NCEP/NCAR reanalysis is a sound choice.

We base our daily rainfall statistical downscaling algorithm on eighteen stations over the main groundwater basins of Israel (https://ims.data.gov.il/ims/1; Table S1; Fig. 1a). This data base provides a continuous record over 1991-2008, which has been quality assured (RostkierEdelstein et al. 2016; Hochman et al. 2020a, b). This comprises an evaluation of each data point with respect to its former and cross-validation with neighboring stations and radar retrievals. Additionally, each data point is compared to other weather-related variables and to the local climatology (Rostkier-Edelstein et al. 2016; Hochman et al. 2020a, b; https://ims.data.gov.il). 
Table 1 The eight CMIP5 models used in the present study. Columns show: modeling center (or group), institute ID, model name, and horizontal resolution $\left({ }^{\circ}\right)$, following Taylor et al. (2012)

\begin{tabular}{|c|c|c|c|}
\hline Modeling center (or group) & Institute ID & Model name (short name) & Resolution $\left({ }^{\circ}\right)$ \\
\hline Canadian Centre for Climate Modelling and Analysis, Canada & CCCMA & $\begin{array}{l}\text { CanESM2 } \\
\text { (CANESM) }\end{array}$ & $2.79 \times 2.81$ \\
\hline National Centre for Atmospheric Research, USA & NCAR & CCSM4 (CCSM) & $0.94 \times 1.25$ \\
\hline Met Office Hadley Centre, England & $\mathrm{MOHC}$ & $\begin{array}{l}\text { HadGEM2-CC } \\
\text { (HadGEM2CC) } \\
\text { HadGEM2-ES } \\
\text { (HadGEM2ES) }\end{array}$ & $\begin{array}{l}1.25 \times 1.88 \\
1.25 \times 1.88\end{array}$ \\
\hline Institut Pierre-Simon Laplace, France & IPSL & $\begin{array}{l}\text { IPSL-CM5A-LR } \\
\text { (IPSL) }\end{array}$ & $1.9 \times 3.75$ \\
\hline Max Planck Institute for Meteorology, Germany & MPI-M & $\begin{array}{l}\text { MPI-ESM-LR } \\
\text { (MPI) }\end{array}$ & $1.87 \times 1.88$ \\
\hline Meteorological Research Institute, Japan & MRI & $\begin{array}{l}\text { MRI-CGCM3 } \\
\text { (MRI) }\end{array}$ & $1.12 \times 1.13$ \\
\hline Norwegian Climate Centre, Norway & $\mathrm{NCC}$ & $\begin{array}{l}\text { NORESM1-M } \\
\text { (NORESM) }\end{array}$ & $1.9 \times 2.5$ \\
\hline
\end{tabular}

\section{Methods}

Possible changes in the characteristics of 'wet' and 'dry' Red Sea Troughs are analyzed. With this aim, the semi-objective synoptic classification (Alpert et al. 2004a) revised in Hochman et al. (2018a) is applied to both NCEP/NCAR and CMIP5 simulations. This method was designed to represent the weather conditions in Israel, and is the most widely used classification in the Eastern Mediterranean. The classification uses SLP, air temperature, and horizontal wind components $U$ and $\mathrm{V}$ at the $850 \mathrm{hPa}$ level over the south-eastern part of the Eastern Mediterranean $\left(27.5^{\circ} \mathrm{N}-37.5^{\circ} \mathrm{N}, 30^{\circ} \mathrm{E}-40^{\circ} \mathrm{E}\right.$; Fig. 1a). Five synoptic classes are defined: Persian Troughs, Cyprus Lows, Highs, 'Sharav' Lows, and Red Sea Troughs. The latter are the focus of the present study.

To differentiate between WRST and DRST and to quantify possible changes in rainfall yield for WRST days, a statistical downscaling algorithm based on past analogs (RostkierEdelstein et al. 2016) is trained on NCEP/NCAR data and then applied to CMIP5 simulations. This method compares a given atmospheric state with those from a long-term past record. Using the minimal Euclidean distance metric (Minkowski metric; Wilks 2011), the analogs for the past atmospheric states are identified and the corresponding observations are taken as proxies for the resulting local weather (Zorita and Von-Storch 1999). The Minkowski metric is computed using twenty-five grid points and the four variables at each grid point. The analogs downscaling algorithm is based on SLP, air temperature, and horizontal wind components $U$ and $\mathrm{V}$ at the $850 \mathrm{hPa}$ level similar to the synoptic classification $\left(27.5^{\circ} \mathrm{N}-37.5^{\circ} \mathrm{N}, 30^{\circ} \mathrm{E}-40^{\circ} \mathrm{E}\right.$; Fig. 1a). It should be noted that the rainfall variable from both reanalysis and CMIP5 models was not used throughout the downscaling procedure.
Instead, the daily rainfall at each station is computed for the closest past analog.

The advantages and disadvantages of statistical downscaling have been rigorously discussed in the literature (e.g., Maraun et al. 2010; Salvi et al. 2016; Lanzante et al. 2018). Statistical downscaling methods are computationally inexpensive compared to dynamical downscaling and often, but not always, provide relatively good results, depending on the availability of high-quality observations (Lanzante et al. 2018). Nonetheless, statistical downscaling may suffer from uncertainty due to non-stationarity of the climate system (e.g., Maraun and Widmann 2018). In particular, one drawback of the analogs' method is that it cannot simulate rain quantities that have not occurred in the past (e.g., Maraun et al. 2010). Still, the analogs' method shows advantages with respect to, e.g., weather regime downscaling techniques, as it provides additional information on the tails of the rainfall distribution (Hochman et al. 2020b). With this aim, the algorithm identifies the closest analogs as past intense/weaker events, and these analogs are then chosen more often by the algorithm. Further details on the method can be found in RostkierEdelstein et al. (2016). Overall, the current method showed an improvement for rainfall estimation compared to lowresolution GCM data (Rostkier-Edelstein et al. 2016; Hochman et al. 2020a, b).

Given the Red Sea Trough days based on the synoptic classification and the rain amounts from the analogs downscaling algorithm, we then distinguish between WRST and DRST days following the commonly used definition by Tsvieli and Zangvil $(2005,2007)$. According to this definition, a WRST occurs if at least two of the rain stations recorded a daily amount of $0.1 \mathrm{~mm}$ or higher. This threshold corresponds to $\sim 25 \%$ of the rainy days over the main hydrological 
basins of Israel, i.e., the northern and central parts of Israel. This permits us to build two sub-groups of WRSTs and DRSTs for the NCEP/NCAR reanalysis and for the CMIP5 models. The changes in SLP patterns, frequency, persistence, annual cycle, and rain associated with enhanced greenhouse gas concentrations are then quantified.

The computation of the annual cycle of the Red Sea Troughs is based on the method proposed by Alpert et al. (2004b). Daily time series are derived for each of the study periods. Then, the total occurrence of each group was computed with a running mean of 11 days ( \pm 5 days) spanning that specific day. Finally, the results are averaged for every day over the historical (1986-2005) and end of the century (20812100 RCP8.5) periods. The running mean of 11 days was chosen after comparing between different possibilities. Longer averaging periods obscured the main characteristics of the seasonal behavior, whereas shorter periods led to noisy results (Alpert et al. 2004b). The student's $t$ test (for the SLP mean patterns), binomial (for the frequencies and persistence), and bootstrap (for rain) tests are used to compare between future (2081-2100 RCP8.5) and historical (1986-2005) periods at the 5\% significance level for both WRST and DRST groups.

\section{Results}

\subsection{Characteristics of the 'wet' and 'dry' Red Sea Trough for current climate conditions}

The general characteristics of the Red Sea Trough are analyzed for the recent time period (1986-2005). The mean SLP composite maps of WRST and DRST for the NCEP/NCAR reanalysis are shown in Fig. 1. For the WRST, a tilt in the horizontal trough's axis towards the Mediterranean Sea is identified (Fig. 1a), which is not the case for the DRST (Fig. 1b). On average, WRST conditions display lower SLP values than DRST for most of the investigated area, with values often exceeding $1 \mathrm{hPa}$ (Fig. 1c). These lower values extend from the southernmost part of Israel i.e., the Red Sea and expand towards the north.

The maps obtained for the individual CMIP5 model simulations for WRST (Figure S1) and DRST (Figure S2) for recent climate conditions are compared to the NCEP/NCAR maps (Fig. 1). The CMIP5 models capture comparatively well the spatial pattern of both Red Sea Trough sub-groups, although some deviations are identified, particularly in terms of the geographical location of the trough's axis and depth. Regarding the WRST cases, five out of the eight models (CANESM, CCSM, IPSL, MPI and NORESM) display a clear trough axis with a horizontal tilt towards the Mediterranean Sea (Figure S1). Some variations are also noticed with regard to the pressure gradient over the region, but three out of the eight models (CANESM, CCSM and NORESM) adequately capture both the range of absolute SLP values and the pressure gradients (Figure S1). Concerning the DRST cases, five out of the eight models (CANESM, HadGEM2CC, HadGEM2ES, IPSL and NORESM) show a subdued trough, also displaying a more easterly axis orientation (Figure S2) as may be expected by the representation of this type of systems in the NCEP/NCAR reanalysis.

For the recent period, CMIP5 models slightly underestimate the number of WRST and DRST with respect to NCEP/NCAR reanalysis. Specifically, the WRST (DRST) occurrence in the multi-model mean is $5.1 \%(16.5 \%)$ while in NCEP/NCAR reanalysis, the frequency is $5.8 \%(17.9 \%$; Table 2). Figures $5 \mathrm{e}$ and 6e suggest that the small underestimation of WRST (DRST) frequency in the multi-model ensemble mean is mainly situated in the winter season. Moreover, the models slightly overestimate (underestimate) the persistence of the WRST (DRST), with a probability of persistence in the multi-model mean of $18.6 \%$ (42.2\%), a value which slightly deviated from the NCEP/NCAR reanalysis value of $17 \%$ (45.9\%; Table 2).

Finally, we study the ability of the downscaled CMIP5 models to capture the shape of the daily rainfall Cumulative Distribution Functions (CDFs). The multi-model mean represents the rainfall distribution relatively well, with some underestimations particularly at $\sim 5-20 \mathrm{~mm}$ (Fig. 2). Indeed, the median daily rainfall yield of the WRST is $0.9 \mathrm{~mm}_{\text {day }}{ }^{-1}$ in the multi-model mean, while the corresponding value for NCEP/NCAR is $1.11 \mathrm{~mm}^{-1}$ day $^{-1}$ (Table 2). We therefore conclude that the multi-model mean captures the characteristics of both Red Sea Trough groups relatively well, thus permitting an evaluation and interpretation of the projected climate change signal.

\subsection{Characteristics of the 'wet' and 'dry' Red Sea Trough for future climate conditions}

We first analyze how the spatial pattern of the WRST and DRST cases changes under enhanced greenhouse gas forcing. When comparing the CMIP5 XXI century projections to the historical period, five out of the eight models (CCSM, HadGEM2CC, HadGEM2ES, MPI and MRI) show significant increases in SLP values for the WRST (white areas in Fig. 3), particularly across the northern part of the domain. This also emerges clearly in the multi-model mean (Fig. 3e). Although the models do not all show an increase in SLP values (cp. Fig. 3 a, f, and h), a tendency towards an enhanced meridional pressure gradient is clear in all cases. For the multimodel mean, this increase is about $0.5 \mathrm{hPa} / 1000 \mathrm{~km}$, which corresponds to about $+9 \%$ (Fig. 3e).

A larger spread among CMIP5 models is found for the DRST case (Fig. 4). In fact, half of the GCMs present an 
Table 2 Changes in frequency, persistence, and downscaled median daily rain of the 'Wet' Red Sea Trough (WRST) and 'Dry' Red Sea Trough (DRST). The periods considered are the historical (1986-2005) and end of the century (2081-2100 RCP8.5). The NCEP/NCAR values are shown for reference. The models are ordered alphabetically. Single asterisk indicates a significant change using the binomial test for the frequencies and persistence, and bootstrap test for the rain at the $5 \%$ significance level. Standard deviations for the multi-model means are given in brackets

\begin{tabular}{|c|c|c|c|c|c|c|}
\hline & WRST & & & DRST & & \\
\hline \multicolumn{7}{|l|}{ Frequency } \\
\hline & 1986-2005 (\%) & $2081-2100(\%)$ & Difference $(\%)$ & 1986-2005 (\%) & $2081-2100(\%)$ & Difference $(\%)$ \\
\hline NCEP/NCAR & 5.8 & & & 17.9 & & \\
\hline CANESM & 3.9 & 3.4 & $-13 *$ & 13.7 & 15.4 & $+12 *$ \\
\hline CCSM & 3.1 & 2.6 & $-16^{*}$ & 14.6 & 16.5 & $+13^{*}$ \\
\hline HadGEM2-CC & 5.7 & 5.5 & -4 & 15.9 & 19.5 & $+23 *$ \\
\hline HadGEM2-ES & 6.4 & 5.5 & $-14^{*}$ & 15.8 & 23.6 & $+49^{*}$ \\
\hline IPSL & 7.8 & 4.9 & $-37 *$ & 23.3 & 27.5 & $+18^{*}$ \\
\hline MPI & 5 & 3.5 & $-30 *$ & 15.8 & 16.6 & +5 \\
\hline MRI & 5.6 & 4.8 & $-14^{*}$ & 17.1 & 20.2 & $+18^{*}$ \\
\hline NORESM & 3.4 & 2.3 & $-32 *$ & 16 & 17.2 & +8 \\
\hline Multi-model mean & $5.1(1.5)$ & $4.1(1.2)$ & $-20(10.8)^{*}$ & $16.5(2.7)$ & 19.6(3.9) & $+19(12.8)^{*}$ \\
\hline \multicolumn{7}{|l|}{ Persistence } \\
\hline & 1986-2005(\%) & $2081-2100(\%)$ & Difference $(\%)$ & 1986-2005 (\%) & 2081-2100 (\%) & Difference $(\%)$ \\
\hline NCEP/NCAR & 17 & & & 45.9 & & \\
\hline CANESM & 16.4 & 17.7 & +8 & 37.6 & 42.2 & $+12 *$ \\
\hline CCSM & 15.4 & 13.4 & $-13^{*}$ & 39.3 & 41.7 & $+6^{*}$ \\
\hline HadGEM2-CC & 17.1 & 20.1 & $+18^{*}$ & 40.5 & 43.9 & $+8^{*}$ \\
\hline HadGEM2-ES & 23.6 & 21.6 & -8 & 37 & 48 & $+30^{*}$ \\
\hline IPSL & 23.7 & 15.9 & $-33^{*}$ & 55.8 & 57.9 & +4 \\
\hline MPI & 18.8 & 16.8 & $-11 *$ & 40 & 38.8 & -3 \\
\hline MRI & 16.5 & 16.4 & -0.6 & 40.1 & 48.8 & $+22 *$ \\
\hline NORESM & 17.5 & 14.3 & $-18^{*}$ & 47.3 & 45.6 & -4 \\
\hline Multi-model mean & $18.6(3)$ & $17(2.6)$ & $-9(14.8)^{*}$ & $42.2(5.9)$ & $45.9(5.5)$ & $+9(11)^{*}$ \\
\hline \multicolumn{7}{|l|}{ Rain } \\
\hline & 1986-2005 (mm/day) & $2081-2100$ (mm/day) & Difference $(\%)$ & & & \\
\hline NCEP/NCAR & 1.11 & & & & & \\
\hline CANESM & 1.12 & 0.69 & $-38^{*}$ & & & \\
\hline CCSM & 0.69 & 0.48 & $-30 *$ & & & \\
\hline HadGEM2-CC & 1.11 & 0.59 & $-47^{*}$ & & & \\
\hline HadGEM2-ES & 1 & 0.48 & $-52 *$ & & & \\
\hline IPSL & 0.72 & 0.43 & $-40^{*}$ & & & \\
\hline MPI & 0.86 & 0.47 & $-45^{*}$ & & & \\
\hline MRI & 1.21 & 0.98 & $-20 *$ & & & \\
\hline NORESM & 0.47 & 0.47 & 0 & & & \\
\hline Multi-model mean & $0.9(0.24)$ & $0.57(0.17)$ & $-37(16)^{*}$ & & & \\
\hline
\end{tabular}

increase in SLP values, while the other half a decrease. The multi-model mean suggests a predominant tendency towards lower SLP values, particularly over the northern part of the domain (Fig. 4e). Similar to WRST, the multi-model mean also suggests an increase in the meridional pressure gradient of $\sim 0.3 \mathrm{hPa} / 1000 \mathrm{~km}$, which is equivalent to about $+6 \%$ (Fig. $4 \mathrm{e}$ ). Thus, both WRST and DRST may be on average associated with stronger zonal winds under future climate conditions. However, the relatively large spread among models, particularly for the DRST cases, does not permit a robust conclusion. On the other hand, the models agree on an average, showing a significant decrease (increase) in the occurrence of the WRST (DRST) by $-20 \%(+19 \%)$ under 


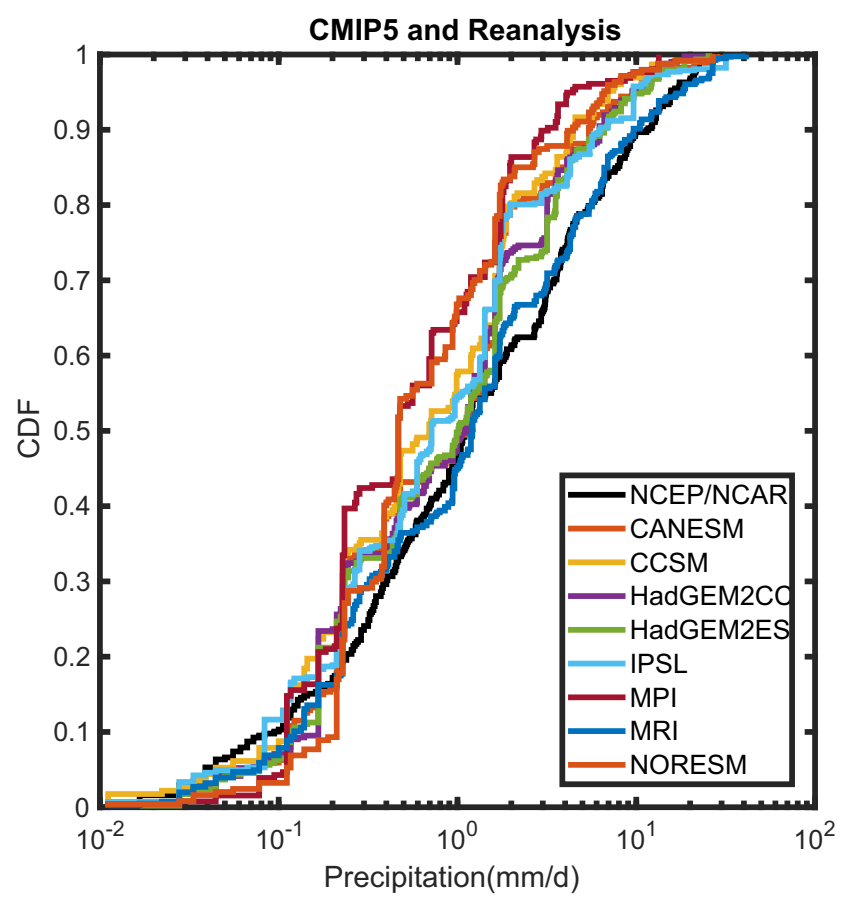

Fig. 2 Daily rain CDFs (mm day ${ }^{-1}$ ) for 'Wet' Red Sea Trough (WRST) days according to the CMIP5 models downscaled by the analogs' method for 1986-2005. Daily rainfall is computed as the average of eighteen rain stations over Israel (Fig. 1a; Table S1)

future climate conditions (Table 2). Moreover, six out of the eight models show a significant decrease (increase) in the persistence of the WRST (DRST) by $-9 \%(+9 \%)$ on average (Table 2).

Next, the annual cycle of the WRST and DRST is analyzed and compared for the two relevant periods. A large portion of the decrease in the frequency of the WRST is found in the transition seasons (Fig. 5), a fact that is also clearly reflected in the multi-model mean (Fig. 5e). Specifically, five out of the eight models (CCSM, HadGEM2CC, IPSL, MPI and MRI) show a decrease in the occurrence of the WRST in both spring and autumn. The other three models (CANESM, HadGEM2ES, and NORESM) show the decrease only in one of the transition seasons. Regarding the DRST, the increased frequency takes place primarily throughout the wet season, i.e., autumn, winter and spring (Fig. 6). This is also visible in the multi-model mean (Fig. 6e) with a relatively low spread among the models.

These changes in the frequency and persistence of DRST and WRST conditions imply a decrease in rainfall over the area, particularly for spring and autumn. Specifically, we investigate the changes in the WRST in terms of the CDFs of daily rainfall. Figure 7 shows the downscaled daily rain CDFs for each model and the multi-model mean for the end of the XXI century compared to the reference period 1986-2005. While some models show small (notably MRI) and others large deviations (CANESM, IPSL, both HadGEM versions) compared to the current period, all models agree on an average reduction of daily rainfall except for very low values (Fig. 7). In total, the rainfall shows a statistically significant and quasi linear reduction, associated with WRST conditions. In numbers, we find a decrease from 0.9 to $0.57 \mathrm{~mm}$ per day on average (Table 2), which corresponds to a reduction by $-37 \%$ (Table 2). The range between the individual models is large, with values from $-20 \%$ (MRI) to $-52 \%$ (HadGEM2ES). These large changes in rainfall amounts will have considerable implications on the hydrological cycle in the region.

\section{Summary and conclusions}

Understanding the changes in Eastern Mediterranean weather regimes and its impacts on rainfall is an important task for developing regional climate change scenarios. While considerable attention has been given to Mediterranean cyclones, other important phenomena for regional rainfall conditions, like the Red Sea Trough, have received less consideration. This is particularly the case within the context of climate change. The assessment of the characteristics of both Red Sea Trough modes is most relevant in terms of the availability of water resources in a changing climate, especially given the observed and projected reduction in rainfall ascribed to the Cyprus Low system (e.g., Alpert et al. 2004a; Hochman et al. 2018a). In the present study, the possible changes in the characteristics of both the 'wet' and 'dry' Red Sea Trough conditions in a warming world are studied. We use eight statistically downscaled CMIP5 models for the recent (1986-2005) and end of the century periods (20812100; RCP8.5).

The comparison between the model simulations for recent climate conditions to the reanalysis revealed that the CMIP5 models can capture the general characteristics of WRST and DRST over the study area. Regarding the future climate projections, we find a number of important changes in the properties of WRSTs and DRSTs compared to the recent period. The CMIP5 models project on average an increase in the meridional pressure gradient both for WRST and DRST days. This implies that both modes of the Red Sea Trough may be associated with stronger horizontal winds in future decades. The WRST occurrence and persistence are projected to significantly decline, while these properties may significantly increase for DRST conditions. We specifically provide evidence that the decline in the frequency of the WRST may primarily affect the transition seasons, while the increase in the DRST frequency takes place across the wet season, 

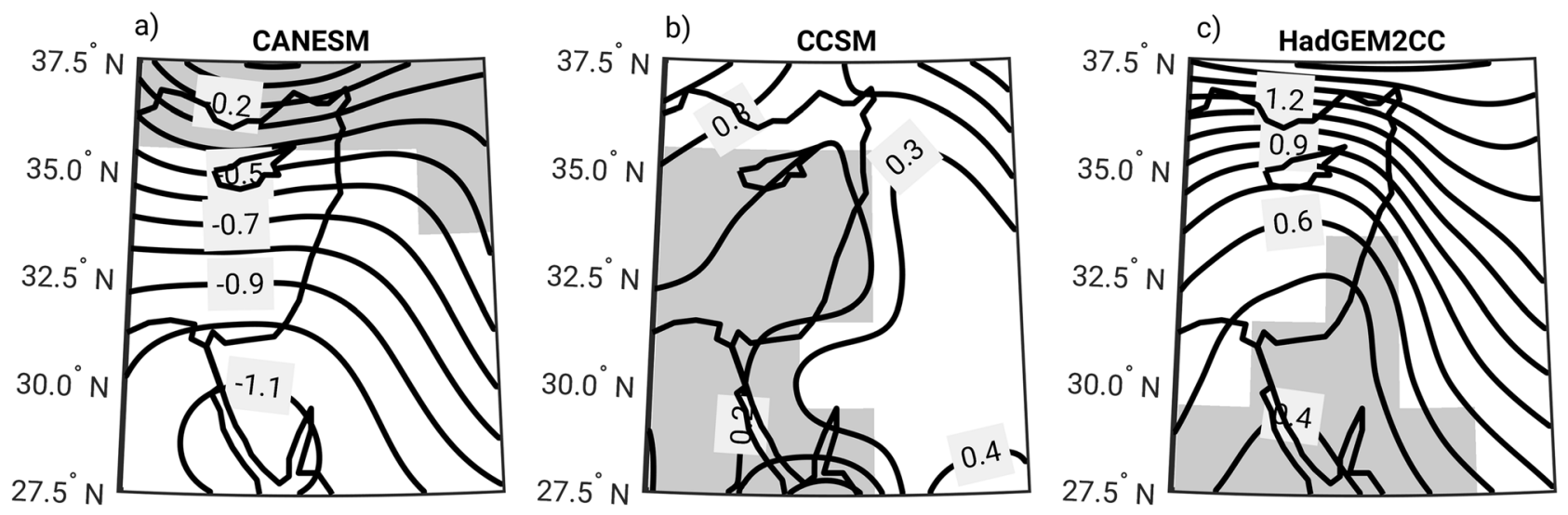

$30.0^{\circ} \mathrm{E} 32.5^{\circ} \mathrm{E} 35.0^{\circ} \mathrm{E} 37.5^{\circ} \mathrm{E} 40.0^{\circ} \mathrm{E}$

$30.0^{\circ} \mathrm{E} 32.5^{\circ} \mathrm{E} 35.0^{\circ} \mathrm{E} 37.5^{\circ} \mathrm{E} 40.0^{\circ} \mathrm{E}$

$30.0^{\circ} \mathrm{E} 32.5^{\circ} \mathrm{E} 35.0^{\circ} \mathrm{E} 37.5^{\circ} \mathrm{E} 40.0^{\circ} \mathrm{E}$
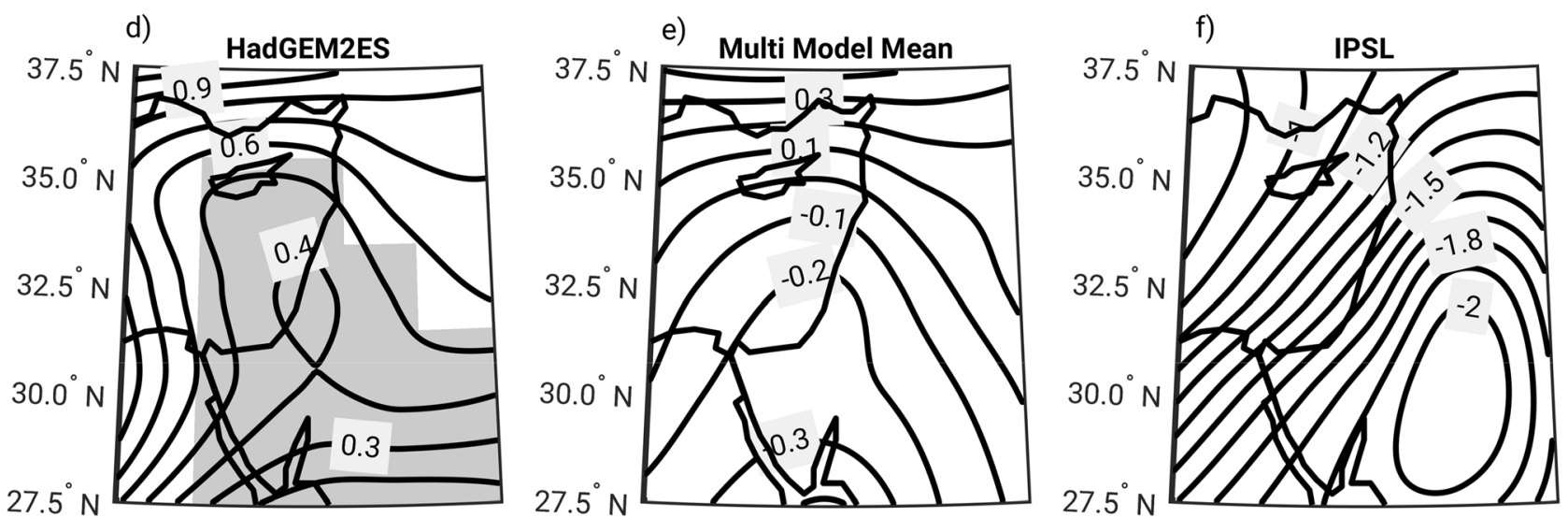

$30.0^{\circ} \mathrm{E} 32.5^{\circ} \mathrm{E} 35.0^{\circ} \mathrm{E} 37.5^{\circ} \mathrm{E} 40.0^{\circ} \mathrm{E} \quad 30.0^{\circ} \mathrm{E} 32.5^{\circ} \mathrm{E} 35.0^{\circ} \mathrm{E} 37.5^{\circ} \mathrm{E} 40.0^{\circ} \mathrm{E} \quad 30.0^{\circ} \mathrm{E} 32.5^{\circ} \mathrm{E} 35.0^{\circ} \mathrm{E} 37.5^{\circ} \mathrm{E} 40.0^{\circ} \mathrm{E}$

g)

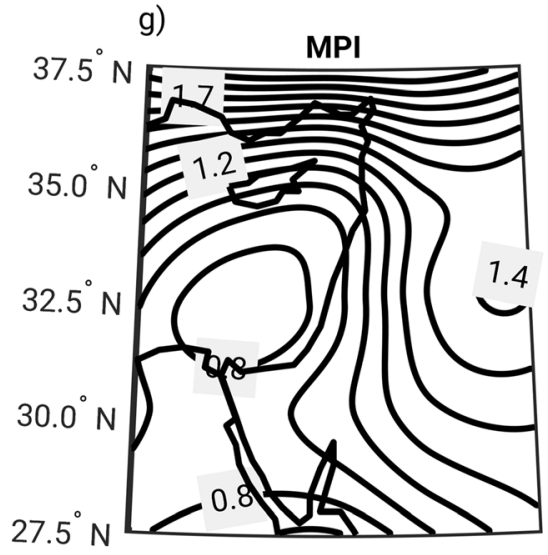

h)

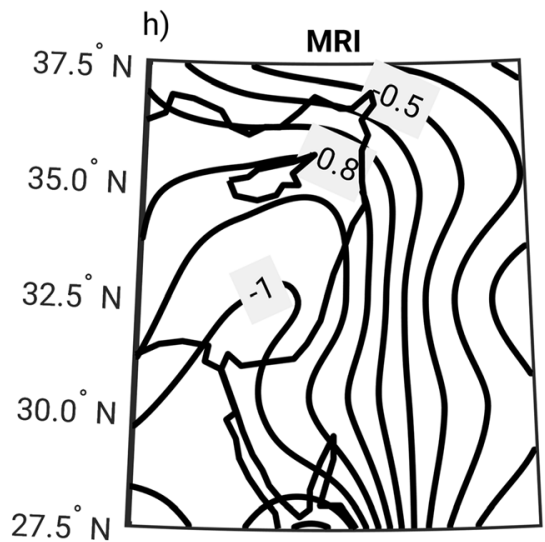

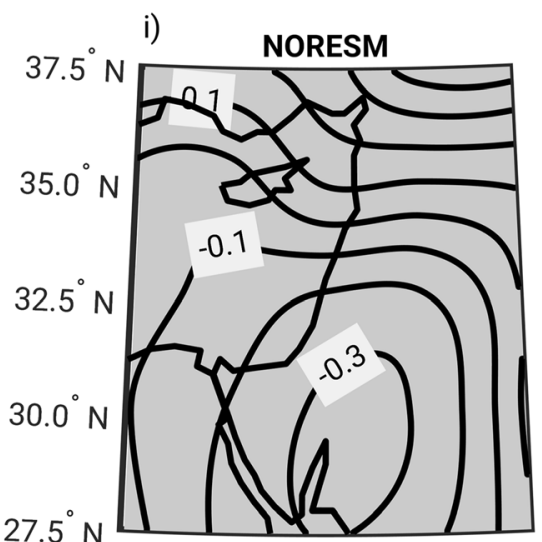

$30.0^{\circ} \mathrm{E} 32.5^{\circ} \mathrm{E} 35.0^{\circ} \mathrm{E} 37.5^{\circ} \mathrm{E} 40.0^{\circ} \mathrm{E} \quad 30.0^{\circ} \mathrm{E} 32.5^{\circ} \mathrm{E} 35.0^{\circ} \mathrm{E} 37.5^{\circ} \mathrm{E} 40.0^{\circ} \mathrm{E} \quad 30.0^{\circ} \mathrm{E} 32.5^{\circ} \mathrm{E} 35.0^{\circ} \mathrm{E} 37.5^{\circ} \mathrm{E} 40.0^{\circ} \mathrm{E}$

Fig. 3 Difference between the mean sea level pressure $(\mathrm{hPa})$ of 'Wet' Red Sea Trough (WRST) composites for 2081-2100 (RCP8.5) versus 1986-2005 periods as simulated by CMIP5 models (panels a-i). The

i.e., from September to May. These new findings suggest that the projected decrease in the frequency of Cyprus Lows (Hochman et al. 2018a) may be associated with an increase in DRSTs as hypothesized by Alpert et al. (2004a). On the other hand, the decrease in the occurrence multi-model mean sea level pressure difference is shown in panel e. Changes are significant using the student's $t$ test at the $5 \%$ significance level except for grid points shaded in gray

of WRSTs may partially be compensated by an increase in the occurrence of the Persian Trough in the transition seasons (Hochman et al. 2018a, 2018b). This indicates a trend towards drier conditions throughout the wet season, 


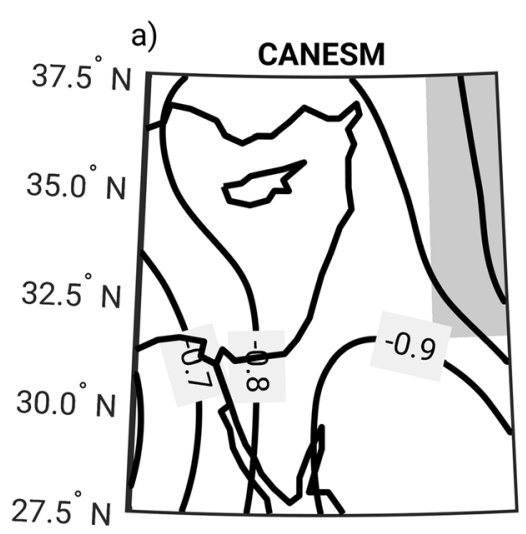

$30.0^{\circ} \mathrm{E} 32.5^{\circ} \mathrm{E} 35.0^{\circ} \mathrm{E} 37.5^{\circ} \mathrm{E} 40.0^{\circ} \mathrm{E}$ d)

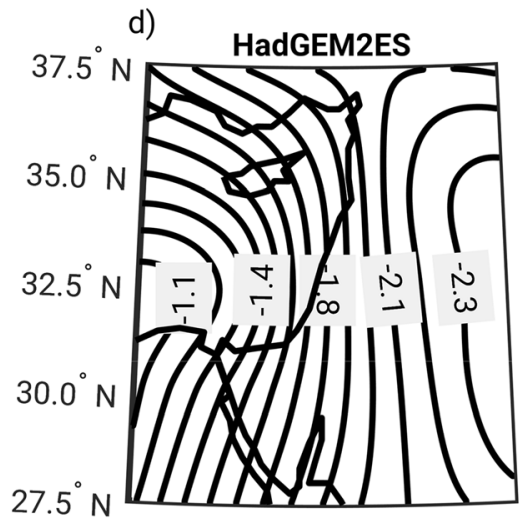

$30.0^{\circ} \mathrm{E} 32.5^{\circ} \mathrm{E} 35.0^{\circ} \mathrm{E} 37.5^{\circ} \mathrm{E} 40.0^{\circ} \mathrm{E}$

g)

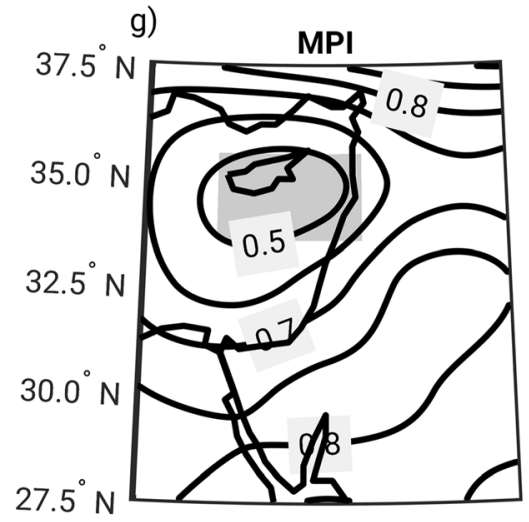

$30.0^{\circ} \mathrm{E} 32.5^{\circ} \mathrm{E} 35.0^{\circ} \mathrm{E} 37.5^{\circ} \mathrm{E} 40.0^{\circ} \mathrm{E}$

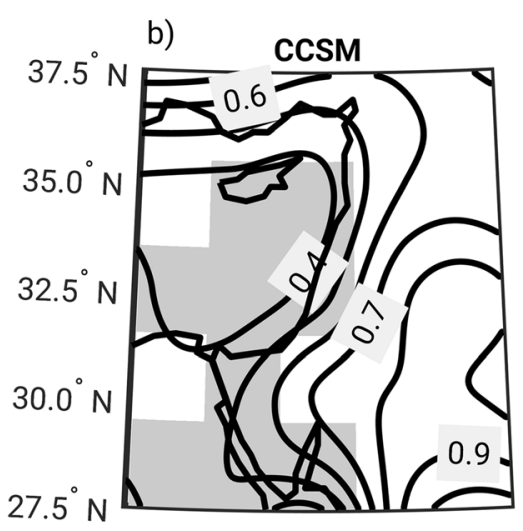

$30.0^{\circ} \mathrm{E} 32.5^{\circ} \mathrm{E} 35.0^{\circ} \mathrm{E} 37.5^{\circ} \mathrm{E} 40.0^{\circ} \mathrm{E}$

e) Multi Model Mean

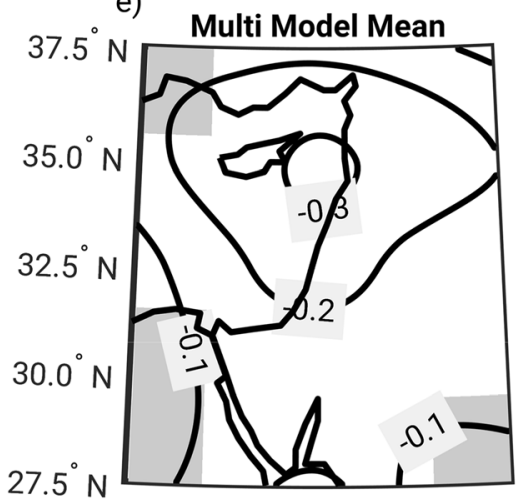

$30.0^{\circ} \mathrm{E} 32.5^{\circ} \mathrm{E} 35.0^{\circ} \mathrm{E} 37.5^{\circ} \mathrm{E} 40.0^{\circ} \mathrm{E}$

h)

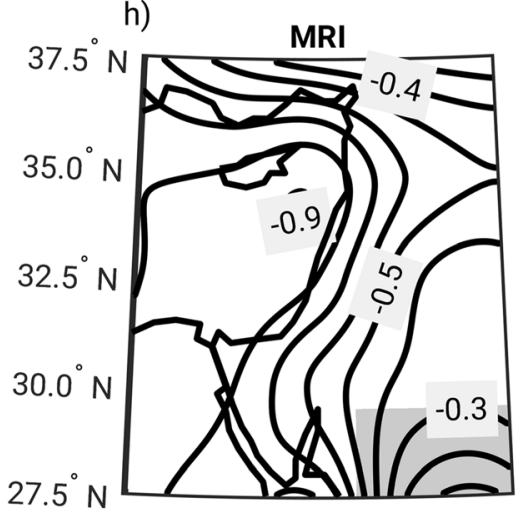

$30.0^{\circ} \mathrm{E} 32.5^{\circ} \mathrm{E} 35.0^{\circ} \mathrm{E} 37.5^{\circ} \mathrm{E} 40.0^{\circ} \mathrm{E}$

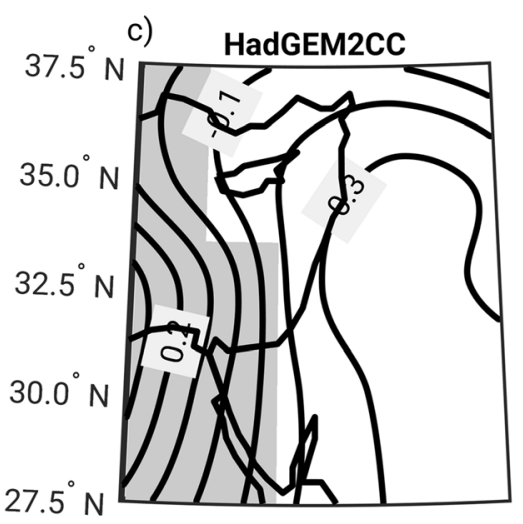

$30.0^{\circ} \mathrm{E} 32.5^{\circ} \mathrm{E} 35.0^{\circ} \mathrm{E} 37.5^{\circ} \mathrm{E} 40.0^{\circ} \mathrm{E}$

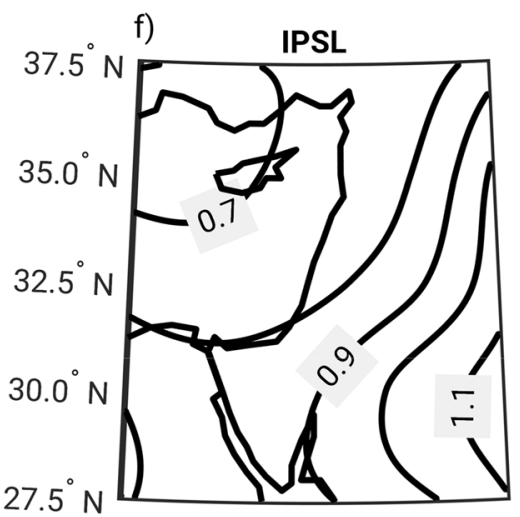

$30.0^{\circ} \mathrm{E} 32.5^{\circ} \mathrm{E} 35.0^{\circ} \mathrm{E} 37.5^{\circ} \mathrm{E} 40.0^{\circ} \mathrm{E}$

i)

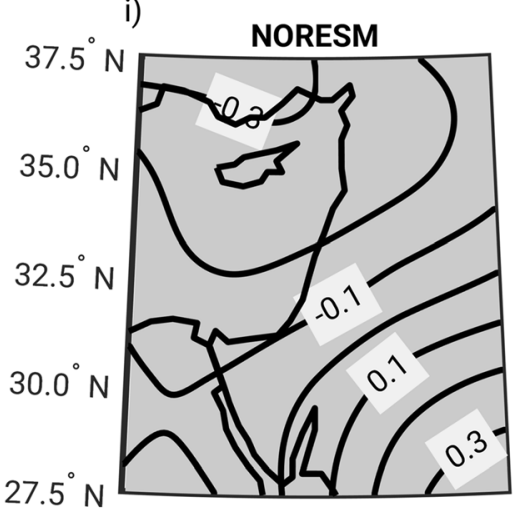

$30.0^{\circ} \mathrm{E} 32.5^{\circ} \mathrm{E} 35.0^{\circ} \mathrm{E} 37.5^{\circ} \mathrm{E} 40.0^{\circ} \mathrm{E}$

Fig. 4 Same as Fig. 3 but for the 'Dry' Red Sea Trough (DRST)

and an extended autumn season dominated by DRST conditions.

The changes in the dynamical properties of the WRST also influence its daily rainfall yield. The CMIP5 models considered here indicate that the average rainfall yield on a WRST day will significantly decrease in the future. Specifically, the statistical downscaling algorithm based on past analogs operated on the CMIP5 model simulations suggests that the daily rainfall yield on a WRST day will decrease on average by $-37 \%$, relative to present day. For the individual models, the values range from -20 to $-52 \%$.

Our findings are in line with a poleward shift of the midlatitude jet stream on zonal and annual average, also associated with a northward shift of the mid-latitude storm tracks (e.g., Barnes and Polvani 2013; Shaw et al. 2016; Tamarin-Brodsky and Kaspi 2017). While these changes may be quite different 


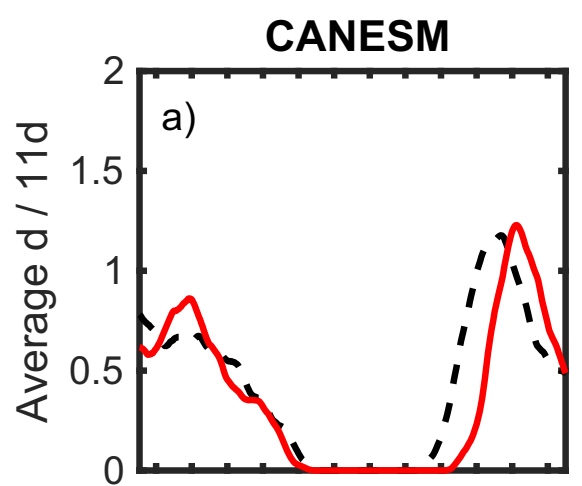

123456789101112

Months

HadGEM2ES
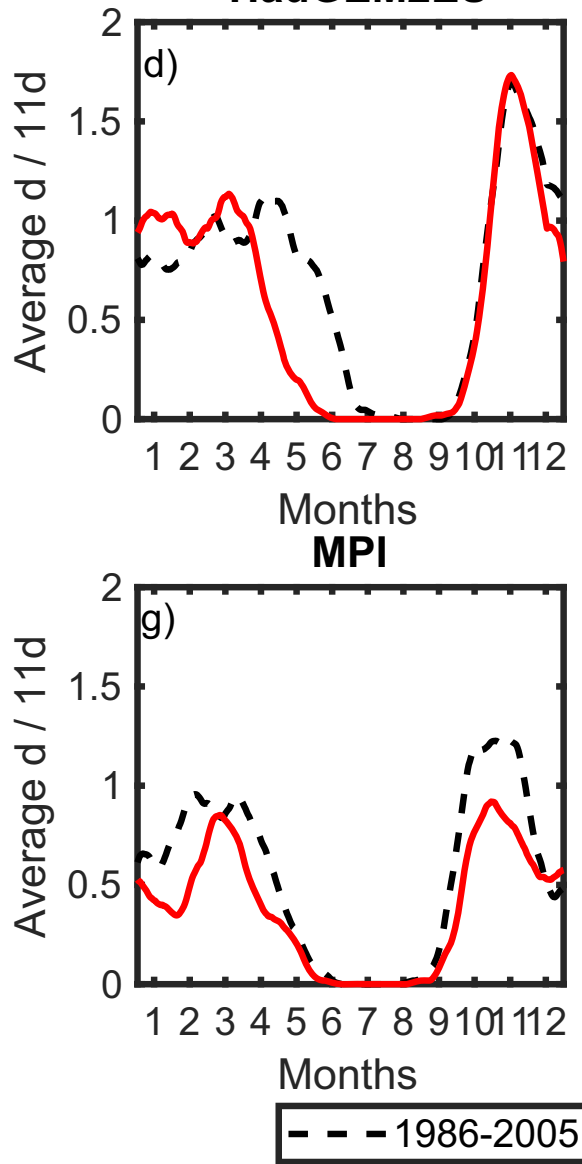

Fig. 5 Differences in the annual cycle of 'Wet' Red Sea Trough (WRST) for 2081-2100 RCP8.5 (red solid lines) with respect to 1986-2005 (black dashed lines) periods as simulated by CMIP5 models (panels a-i). The
CCSM

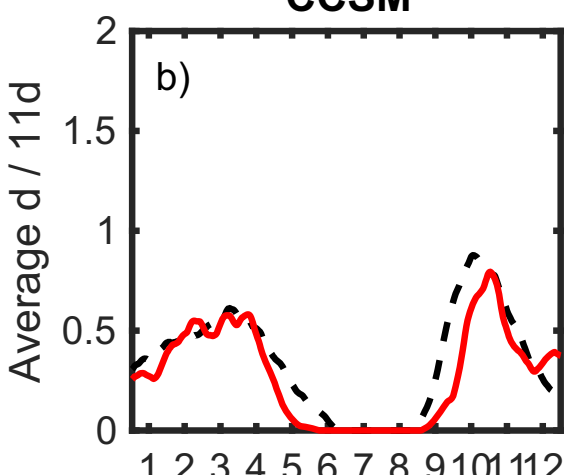

Months

Multi Model Ensemble Mean

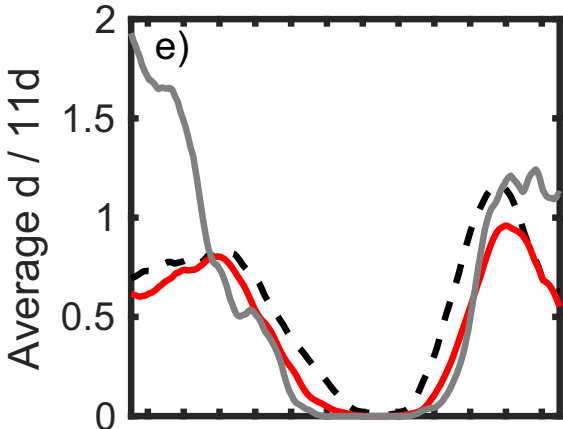

123456789101112 Months

MRI

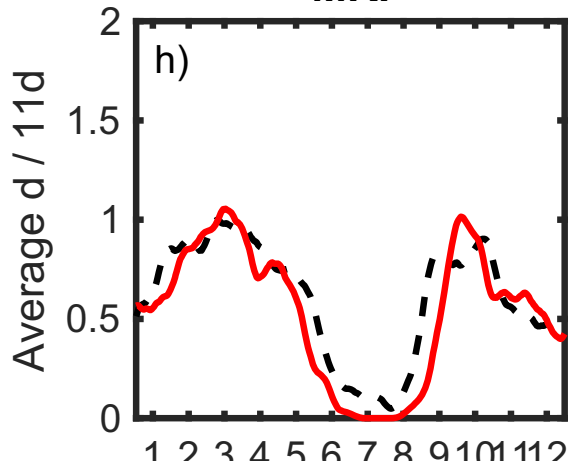

Months
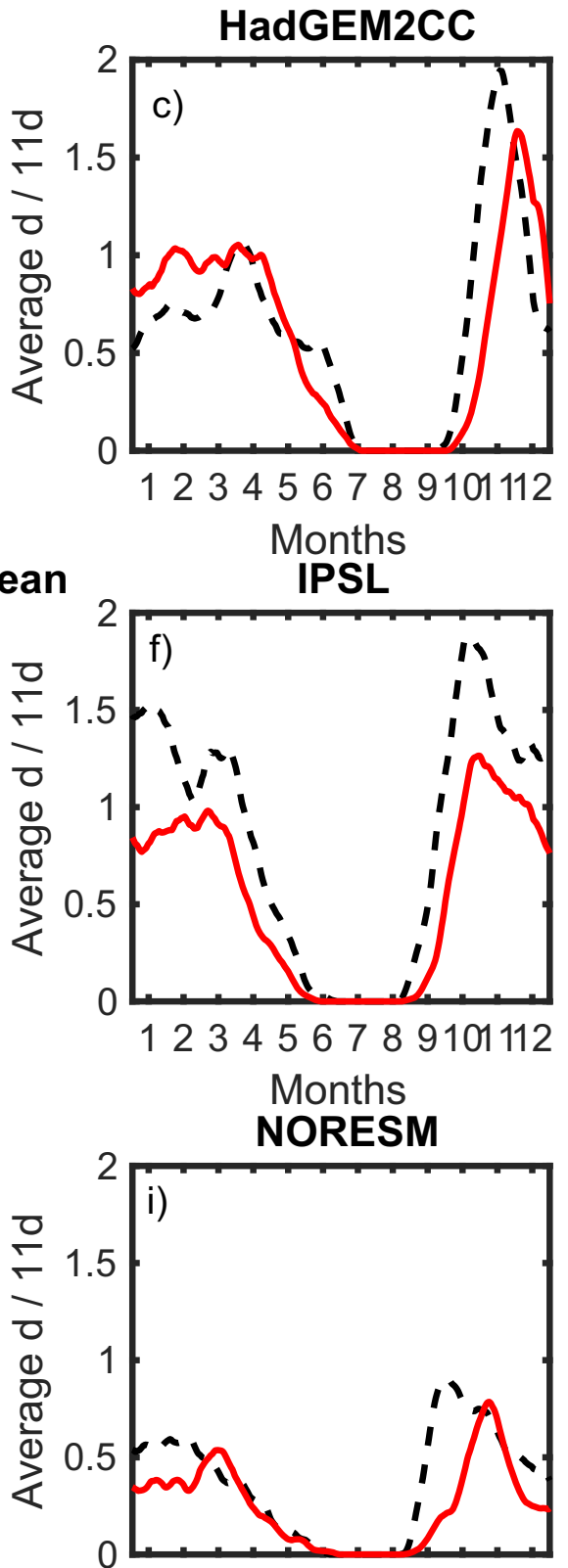

123456789101112 Months

\section{-2081-2100 RCP8.5 - NCEP/NCAR 1986-2005}

multi-model mean annual cycle is shown in panel e. The NCEP/NCAR reanalysis annual cycle of WRST is shown for reference in panel $\mathbf{e}$ (solid grey line) for different seasons (cp. Zappa et al. 2015b), they are associated with the projected inflation of the Hadley cell (Seidel et al. 2008) and may lead to an overall decrease of annual precipitation southward of $50^{\circ} \mathrm{N}$ (Santos et al. 2016). Some studies also project a more dominant positive phase of the
North Atlantic Oscillation (Gillet and Fyfe 2013), which would affect the occurrence and characteristics of the synoptic systems over the Eastern Mediterranean (Hochman et al. 2020a). Specifically, these changes may allow the Red Sea Trough to penetrate further north and in turn influence its 

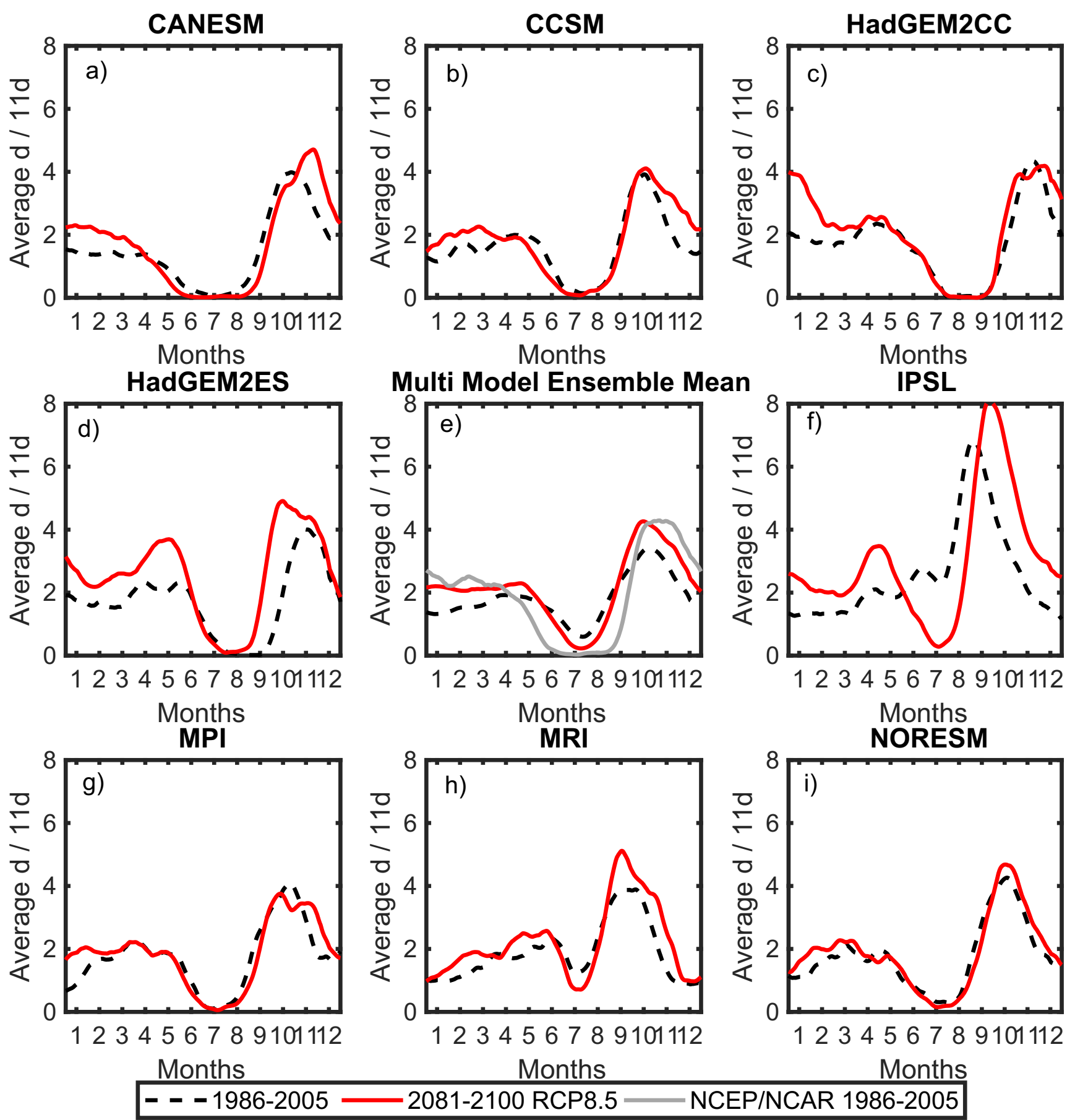

Fig. 6 Same as Fig. 5 but for 'Dry' Red Sea Trough (DRST)

rainfall yield. Potential drivers of these changes may relate to alterations in precipitation-generating thermodynamic processes under future climate conditions, e.g., higher temperatures, enhanced latent heat release, and moisture content at lower levels (Lucarini et al. 2010). Clarifying this result in coarse gridded global simulations is rather difficult and motivates the investigation of an ensemble of regional simulations to identify the underlying drivers.

The above findings offer a clear outline as to the climatic challenges the Eastern Mediterranean and specifically Israel may face in future decades, including alterations in water resources, reduced agricultural potential, and an increase in air 


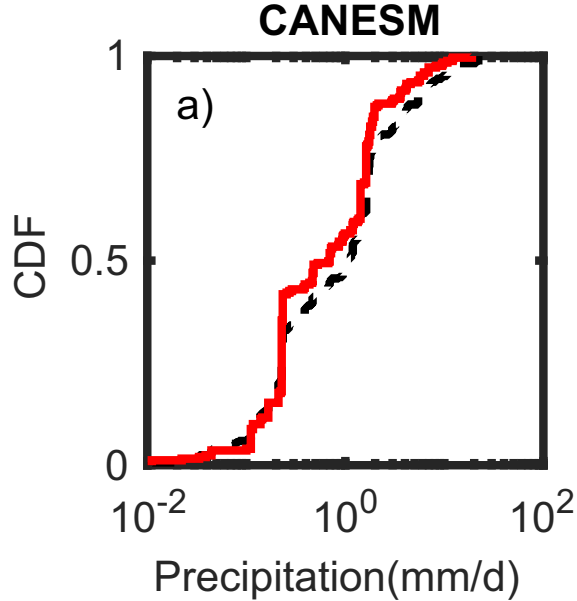

HadGEM2-ES

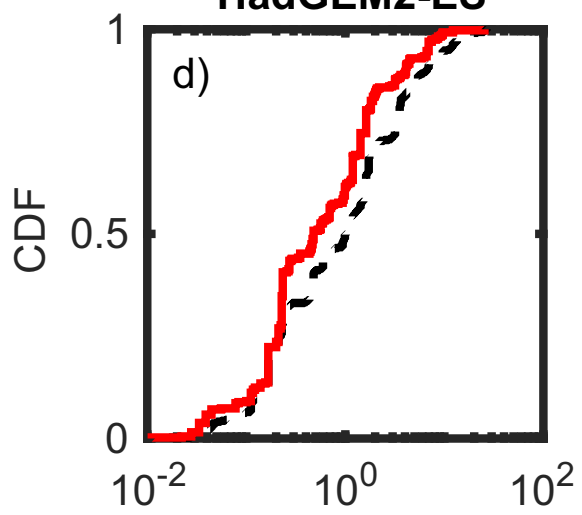

Precipitation $(\mathrm{mm} / \mathrm{d})$

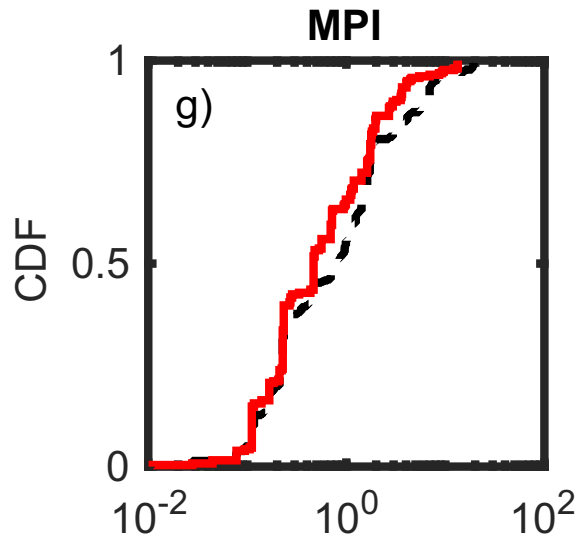

Precipitation $(\mathrm{mm} / \mathrm{d})$

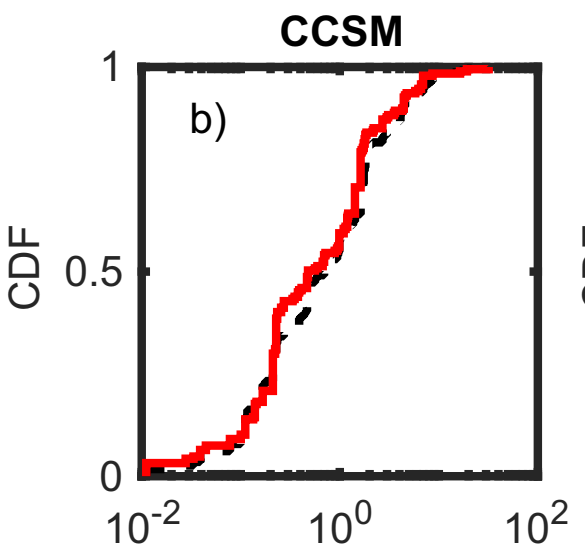

Precipitation $(\mathrm{mm} / \mathrm{d})$

Multi Model Mean

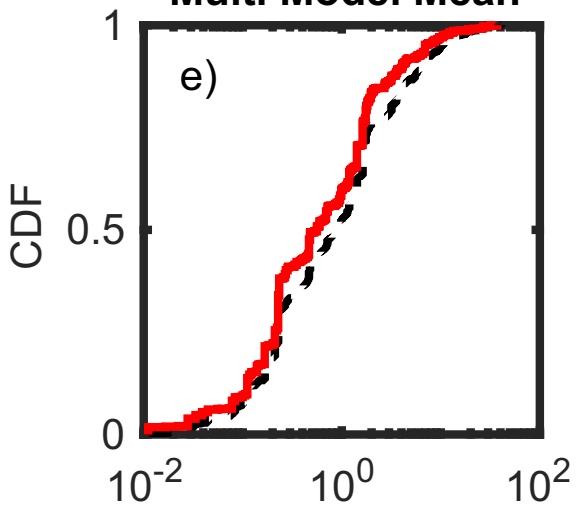

Precipitation $(\mathrm{mm} / \mathrm{d})$

MRI

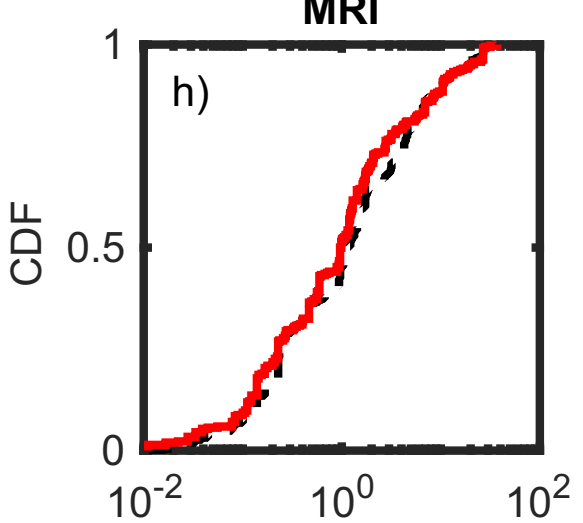

Precipitation $(\mathrm{mm} / \mathrm{d})$

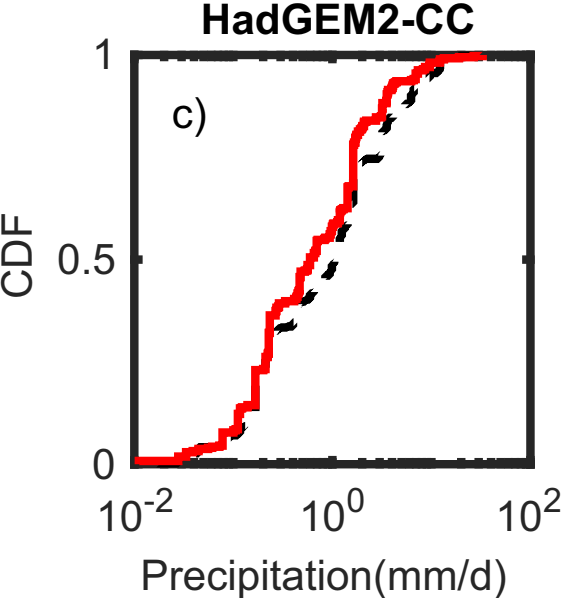

IPSL

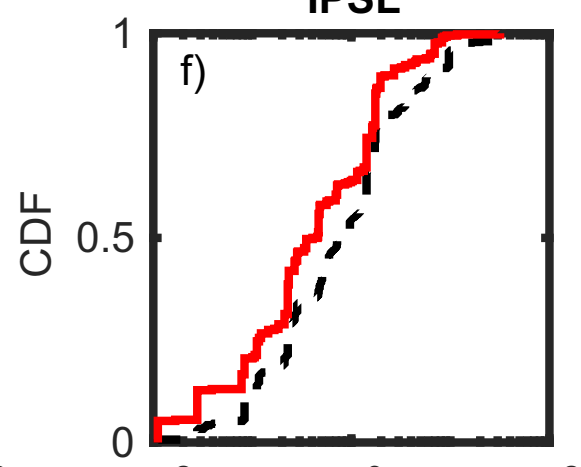

$10^{-2} \quad 10^{0} \quad 10^{2}$

Precipitation $(\mathrm{mm} / \mathrm{d})$

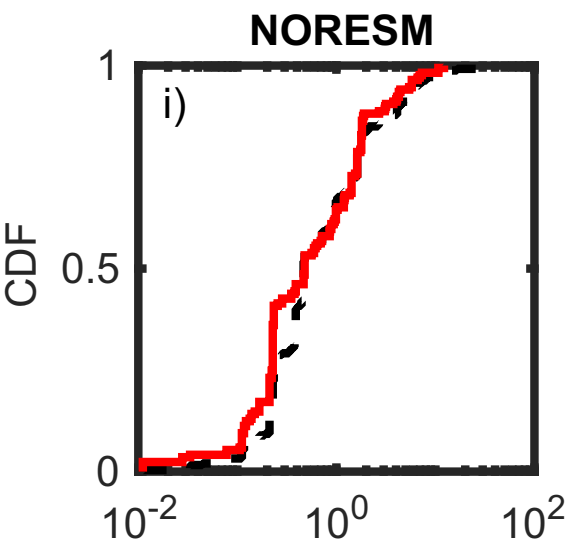

Precipitation $(\mathrm{mm} / \mathrm{d})$

$$
\text { - - - } 1986 \text { - } 2005 \longrightarrow 2081 \text { - } 2100 \text { RCP8.5 }
$$

Fig. 7 Daily rain CDFs (mm day $\left.{ }^{-1}\right)$ on 'wet' Red Sea Trough days according to the CMIP5 models downscaled by the analogs' method for 1986-2005 (black dashed lines) with respect to 2081-2100 RCP8.5 (red solid lines). Daily rainfall is computed as the average of eighteen rain stations over Israel (Fig. 1a; Table S1)

resources management, and regional climate change adaptation measures (Loizidou et al. 2016; Lange 2019). 
Acknowledgments We thank NCEP/NCAR for the reanalysis data. We also thank the Coupled Model Inter-comparison Project Phase 5 (CMIP5) for supplying the climate model data. This paper is a contribution to the Hydrological cycle in the Mediterranean Experiment (HyMeX) community.

Authors' contributions All authors have contributed to the conceptual development of the study. AH drafted the first version of the manuscript and prepared the figures. All authors contributed through discussions and revisions.

Funding Open Access funding enabled and organized by Projekt DEAL. $\mathrm{AH}$ is funded by the German Helmholtz Association grant number, 12.01.02. JGP thanks AXA research fund for support (https://axaresearch.org/en/project/joaquim-pinto)

Data availability The paper and/or the supplementary materials contain or provide instructions to access all the data needed to evaluate the conclusions drawn in the paper. Additional data are available from the corresponding author upon request.

\section{Compliance with ethical standards}

Competing interests The authors declare that they have no competing interests.

Open Access This article is licensed under a Creative Commons Attribution 4.0 International License, which permits use, sharing, adaptation, distribution and reproduction in any medium or format, as long as you give appropriate credit to the original author(s) and the source, provide a link to the Creative Commons licence, and indicate if changes were made. The images or other third party material in this article are included in the article's Creative Commons licence, unless indicated otherwise in a credit line to the material. If material is not included in the article's Creative Commons licence and your intended use is not permitted by statutory regulation or exceeds the permitted use, you will need to obtain permission directly from the copyright holder. To view a copy of this licence, visit http://creativecommons.org/licenses/by/4.0/.

\section{References}

Alpert P, Osetinsky I, Ziv B, Shafir H (2004a) Semi-objective classification for daily synoptic systems: application to the Eastern Mediterranean climate change. Int J Climatol 24:1001-1011. https://doi.org/10.1002/joc. 1036

Alpert P, Osetinsky I, Ziv B, Shafir H (2004b) A new seasons' definition based on the classified daily synoptic systems, an example for the Eastern Mediterranean. Int J Climatol 24:1013-1021. https://doi. org/10.1002/joc. 1037

Alpert P, Price C, Krichak SO, Ziv B, Saaroni H, Osetinski I, Barkan J, Kishcha P (2005) Tropical tele-connections to the Mediterranean climate and weather. Adv Geosci 2:157-160. https://doi.org/10. 5194/adgeo-2-157-2005

Ashbel D (1938) Great floods in Sinai Peninsula, Palestine, Syria and the Syrian desert, and the influence of the Red Sea on their formation. Q J R Meteorol Soc 64:635-639. https://doi.org/10.1002/qj. 49706427716

Awad AM, Almazroui M (2016) Climatology of the winter Red Sea Trough. Atmos Res 182:20-29. https://doi.org/10.1016/j.atmosres. 2016.07.019

Awad AM, Mashat AWS (2019) Climatology of the Autumn Red Sea Trough. Theor Appl Climatol 135:1554-1558. https://doi.org/10. 1007/s00704-018-2453-1
Barnes EA, Polvani LM (2013) Response of the midlatitude jets and of their variability to increased greenhouse gases in CMIP5 models. J Clim 26:7117-7135. https://doi.org/10.1175/jcli-d-12-00536.1

De Vries AJ, Tyrlis E, Edry D, Krichak SO, Steil B, Lelieveld J (2013) Extreme precipitation events in the Middle East: dynamics of the Active Red Sea Trough. J Geophys Res-Atmos 118(13):7087-7108. https://doi.org/10.1002/jgrd.50569

El Fandy MG (1948) The effect of the Sudan monsoon low on the development of thundery conditions in Egypt, Palestine and Syria. Q J R Meteorol Soc 74:31-38. https://doi.org/10.1002/qj.49707431904

Gasch P, Rieger D, Walter C, Khain P, Levi Y, Knippertz P, Vogel B (2017) Revealing the meteorological drivers of the 2017 severe dust event in the Eastern Mediterranean. Atmos Chem Phys 17:1357313604. https://doi.org/10.5194/acp-17-13573-2017

Gillet NP, Fyfe JC (2013) Annular mode changes in the CMIP5 simulations. Geophys Res Lett 40:1189-1193. https://doi.org/10.1002/grl. 50249

Giorgi F (2006) Climate change hot spots. Geophys Res Lett 33:L08707. https://doi.org/10.1029/2006g1025734

Giorgi F, Jones C, Asrar GR (2009) Addressing climate information needs at the regional level: the CORDEX Framework. WMO Bull $58: 175$

Hochman A, Harpaz T, Saaroni H, Alpert P (2018a) Synoptic classification in $21^{\text {st }}$ century CMIP5 predictions over the Eastern Mediterranean with focus on cyclones. Int J Climatol 38:14761483. https://doi.org/10.1002/joc.5260

Hochman A, Harpaz T, Saaroni H, Alpert P (2018b) The seasons' length in $21^{\text {st }}$ century CMIP5 projections over the Eastern Mediterranean. Int J Climatol 38:2627-2637. https://doi.org/10.1002/joc.5448

Hochman A, Alpert P, Harpaz T, Saaroni H, Messori G (2019) A new dynamical systems perspective on atmospheric predictability: Eastern Mediterranean weather regimes as a case study. Sci Adv 5:eaau0936. https://doi.org/10.1126/sciadv.aau0936

Hochman A, Alpert P, Kunin P, Rostkier-Edelstein D, Harpaz T, Saaroni $\mathrm{H}$, Messori G (2020a) The dynamics of cyclones in the twenty-first century; the Eastern Mediterranean as an example. Clim Dyn 54: 561-574. https://doi.org/10.1007/s00382-019-05017-3

Hochman A, Kunin P, Alpert P, Harpaz T, Saaroni H, Rostkier-Edelstein D (2020b) Weather regimes and analogues downscaling of seasonal precipitation; a case study over Israel. Int J Climatol 40:2062-2077. https://doi.org/10.1002/joc.6318

Huth R (2019) Special issue: value: validating and integrating downscaling methods for climate change research. Int J Climatol 39:i-iv

Kahana R, Ziv B, Enzel Y, Dayan U (2002) Synoptic climatology of major floods in the Negev Desert, Israel. Int J Climatol 22:867882. https://doi.org/10.1002/joc.766

Kalnay E, Kanamitsu M, Kistler R, Collins W, Deaven D, Gandin L, Iredell M, Saha S, White G, Woollen J, Zhu Y, Chelliah M, Ebisuzaki W, Higgins W, Janowiak J, Mo KC, Ropelewski C, Wang J, Leetmaa A, Reynolds R, Jenne R, Joseph D (1996) The NCEP/NCAR 40-year reanalysis project. Bull Am Meteorol Soc 77: 437-471

Koch J, Dayan U (1992) A synoptic analysis of the meteorological conditions affecting dispersal of pollutants emitted from tall stacks in the coastal plain of Israel. Atmos Environ 26A:2537-2543. https:// doi.org/10.1016/0960-1686(92)90105-t

Krichak SO, Alpert P, Krishnamurti TN (1997) Interaction of topography and atmospheric flow - a possible generator of the Red Sea Trough? Meteorog Atmos Phys 63:149-158. https://doi.org/10.1007/ bf01027381

Krichak SO, Breitgand JS, Feldstein SB (2012) A conceptual model for the identification of Active Red Sea Trough synoptic events over the south-eastern Mediterranean. J Appl Meteorol Climatol 51:962971. https://doi.org/10.1175/jamc-d-11-0223.1 
Kutiel H, Kutiel P (1991) The distribution of autumnal easterly wind spells favoring rapid spread of forest wild fires on Mount Carmel, Israel. GeoJournal 23:147-152. https://doi.org/10.1007/bf00241399

Lange MA (2019) Impacts of climate change on the Eastern Mediterranean and the Middle East and North Africa region and the water-energy nexus. Atmosphere 10(8):455. https://doi.org/10. 3390/atmos10080455

Lanzante JR, Dixon KW, Nath MJ, Whitlock CE, Adams-Smith D (2018) Some pitfalls in statistical downscaling of future climate. Bull Am Meteorol Soc 99:791-803. https://doi.org/10.1175/BAMS-D-17-0046.1

Lionello P, Gacic AF, Planton M, Trigo SR, Ulbrich U (2014) The climate of the Mediterranean region: research progress and climate change impacts. Reg Environ Chang 14:1679-1684. https://doi. org/10.1007/s10113-014-0666-0

Lionello P, Trigo IF, Gil V, Liberato ML, Nissen KM, Pinto JG, Raible CC, Reale M, Tanzarella A, Trigo RM, Ulbrich S (2016) Objective climatology of cyclones in the Mediterranean region: a consensus view among methods with different system identification and tracking criteria. Tellus A 68:1-18. https://doi.org/10.3402/tellusa.v68.29391

Loizidou M, Giannakopoulos C, Bindi M, Konstantinos M (2016) Climate change impacts and adaptation options in the Mediterranean basin. Reg Environ Chang 16:1859-1861. https:// doi.org/10.1007/s10113-016-1037-9

Lorenz EN (1969) Atmospheric predictability as revealed by naturally occurring analogues. J Atmos Sci 26:636-646. https://doi.org/10. 1175/1520-0469(1969)26\%3C636:aparbn\%3E2.0.co;2

Lucarini V, Fraedrich K, Lunkeit F (2010) Thermodynamics of climate change: generalized sensitivities. Atmos Chem Phys 10:9729-9737. https://doi.org/10.5194/acp-10-9729-2010

Maraun D, Widmann M (2018) Statistical downscaling and bias correction for climate research. Cambridge University press, Cambridge. https://doi.org/10.1017/9781107588783

Maraun D, Wetterhall F, Ireson AM, Chandler RE, Kendon EJ, Widmann M, Brienen S, Rust HW, Sauter T, Themessl M, Venema VKC, Chun KP, Goodess CM, Jones RG, Onof C, Vrac M, Thiele-Eich I (2010) Precipitation downscaling under climate change. Recent developments to bridge the gap between dynamical models and the end user. Rev Geophys 48:RG3003. https://doi.org/10.1029/2009rg000314

Maraun D, Widmann M, Gutiérrez JM, Kotlarski S, Chandler RE, Hertig E, Wibig J, Huth R, Wilcke RA (2015) VALUE: a framework to validate downscaling approaches for climate change studies. Earth's Future 3:1-14. https://doi.org/10.1002/2014ef000259

Peleg N, Bartov M, Morin E (2015) CMIP5 predicted climate shifts over the East Mediterranean: implication to the transition region between Mediterranean and semi-arid climates. Int J Climatol 35:2144-2153. https://doi.org/10.1002/joc.4114

Raible CC, Ziv B, Saaroni H, Wild M (2010) Winter cyclonic activity over the Mediterranean Basin under future climate based on the ECHAM5 GCM. Clim Dyn 35:473-488. https://doi.org/10.1007/ s00382-009-0678-5

Rostkier-Edelstein D, Kunin P, Hopson TM, Yubao L, Givati A (2016) Statistical downscaling of seasonal precipitation in Israel. Int J Climatol 36:590-606. https://doi.org/10.1002/joc.4368

Saaroni H, Ziv B, Bitan A, Alpert P (1998) Easterly wind storms over Israel. Theor Appl Climatol 59:61-77. https://doi.org/10.1007/ s007040050013

Saaroni H, Halfon N, Ziv B, Alpert P, Kutiel H (2010) Links between the rainfall regime in Israel and location and intensity of Cyprus Lows. Int J Climatol 30:1014-1025. https://doi.org/10.1002/joc.1912

Saaroni H, Harpaz T, Alpert P, Ziv B (2019) Automatic identification and classification of the northern part of the Red Sea Trough and its application to climatological analysis. Int J Climatol 40(7):36073622. https://doi.org/10.1002/joc.6416

Salvi K, Ghosh S, Ganguly AR (2016) Credibility of statistical downscaling under nonstationary climate. Clim Dyn 46:1991-2023. https:// doi.org/10.1007/s00382-015-2688-9
Samuels R, Hochman A, Baharad A, Givati A, Levi Y, Yosef Y, Saaroni H, Ziv B, Harpaz T, Alpert P (2017) Evaluation and projection of extreme precipitation indices in the Eastern Mediterranean based on CMIP5 multi model ensemble. Int J Climatol 38(5):2280-2297. https://doi.org/10.1002/joc.5334

Santos JA, Belo-Pereira M, Fraga H, Pinto JG (2016) Understanding climate change projections for precipitation over western Europe with a weather typing approach. J Geophys Res-Atmos 121:1170 1189. https://doi.org/10.1002/2015jd024399

Seidel DJ, Fu Q, Randel WJ, Reichler TJ (2008) Widening of the tropical belt in a changing climate. Nat Geosci 1:21-24. https://doi.org/10. 1038/ngeo.2007.38

Shaw TA, Baldwin M, Barnes EA, Caballero R, Garfinkel CI, Hwang YT, Li C, O'Gorman PA, Riviére G, Simpson IR, Voigt A (2016) Storm track processes and the opposing influences of climate change. Nat Geosci 9:656-664. https://doi.org/10.1038/ngeo2783

Shentsis I, Laronne JB, Alpert P (2012) Red Sea Trough flood events in the Negev, Israel (1964 - 2007). Hydrol Sci J 57:42-51. https://doi. org/10.1080/02626667.2011.636922

Tamarin-Brodsky T, Kaspi Y (2017) Enhanced poleward propagation of storms under climate change. Nat Geosci 10:908-913. https://doi. org/10.1038/s41561-017-0001-8

Taylor KER, Stouffer J, Meehl GA (2012) An overview of CMIP5 and the experiment design. Bull Am Meteorol Soc 93:485-498. https:// doi.org/10.1175/bams-d-11-00094.1

Trigo IF, Davies TD, Bigg GR (1999) Objective climatology of cyclones in the Mediterranean region. J Clim 12:1685-1696. https://doi.org/ 10.1175/1520-0442(1999)012\%3C1685:ococit\%3E2.0.co;2

Trigo IF, Bigg GR, Davis TD (2002) Climatology of cyclogenesis mechanisms in the Mediterranean. Mon Weather Rev 130:549-569. https://doi.org/10.1175/1520-0493(2002)130\%3C0549:cocmit\% 3E2.0.co;2

Tsvieli Y, Zangvil A (2005) Synoptic climatological analysis of 'wet' and ‘dry' Red Sea Troughs over Israel. Int J Climatol 25:1997-2015. https://doi.org/10.1002/joc. 1232

Tsvieli Y, Zangvil A (2007) Synoptic climatological analysis of Red Sea Trough and non-Red Sea Trough rain situations over Israel. Adv Geosci 12:137-143. https://doi.org/10.5194/adgeo-12-137-2007

Ulbrich U, Leckebusch GC, Pinto JG (2009) Extratropical cyclones in the present and future climate: a review. Theor Appl Climatol 96:117131. https://doi.org/10.1007/s00704-008-0083-8

Van-Vuuren DP, Edmonds JA, Kainuma M, Riahi K, Weyant J (2011) A special issue on the RCPs. Clim Chang 109:1-4. https://doi.org/10. 1007/s10584-011-0157-y

Wilby RL, Wigley TML (1997) Downscaling general circulation model outputs: a review of methods and limitations. Prog Phys Geogr 21: 530-548. https://doi.org/10.1177/030913339702100403

Wilks DS (2011) Statistical methods in the atmospheric sciences. Academic Press, San Diego. https://doi.org/10.1016/c2017-003921-6

Zappa G, Hawcroft MK, Shaffrey L, Black E, Brayshaw DJ (2015a) Extratropical cyclones and the projected decline of winter Mediterranean precipitation in the CMIP5 models. Clim Dyn 45: 1727-1738. https://doi.org/10.1007/s00382-014-2426-8

Zappa G, Hoskins BJ, Shepherd TG (2015b) Improving climate change detection through optimal seasonal averaging: the case of the North Atlantic jet and European precipitation. J Clim 28:6381-6397. https://doi.org/10.1175/JCLI-D-14-00823.1

Zorita E, Von-Storch H (1999) The Analog method as a simple statistical downscaling technique: comparison with more complicated methods. J Clim 12:2474-2489. https://doi.org/10.1175/15200442(1999)012<2474:TAMAAS>2.0.CO;2

Publisher's note Springer Nature remains neutral with regard to jurisdictional claims in published maps and institutional affiliations. 